\title{
Recommended Employment Model for Silent Community using Smart Technology
}

\author{
Anwar Ali Sathio', Mujeeb ur Rehman Shaikh², Ali Orangzeb Panhwar ${ }^{3}$,M.Afzal Sahito ${ }^{4}$, \\ Abdullah Lakhan ${ }^{5}$ \\ 1, 2,3,4,5 Lab of Information Security and AI, Department of Computer Science and Information \\ Technology,Benazir Bhutto Shaheed University Lyari,Sindh, Pakistan, \\ anwar.sathio@bbsul.edu.pk,mujeebshaikh137@gmail.com, \\ Orangzebpanhwar@gmail.com,Afzalsahito87@gmail.com, abdullahrazalakhan@gmail.com
}

\begin{abstract}
Today, it is the era of Smart Digital Technologies (SDT). The humans are switching their almost personal and official information into digital technology and keeping ${ }^{1}$ intact valid information through cloud computing in less efforts all over the world. Special Need People (SNP) are the part of every society and when we look at the issues related to them; we find it not only in the under developing countries but also face a lot of hindrances in the developed countries. The main motivation behind this research is to overcome the challenges faced by special need community. There are different categories of Special Need People(SNP), but this research focuses on deaf community. When the deaf start or think to start their career, they face a lot of problems in the society. As a result of this, they are leading isolated life from the other people of community. The technology-based model will enable them to initiate the practical life with self-confidence and may easily support their families
\end{abstract}

Key words: Special Need People (SNP), Deaf Community, Smart Digital Technologies (SDT)

\section{INTRODUCTION}

\section{The Deaf Communities}

It is a natural phenomenon that after the birth of a child, it starts speaking with sign language. The child starts lisping in its mother tongue. The child feels motivated in learning different expressions from the parents and surrounding environment. Moreover, when the child grows up, he learns from environment, surroundings and starts sharing their feelings from people who are associated with them. A deaf child also learns from environment but cannot speak and share the feelings. This situation sometimes has identified by their caring persons at an early stage, and sometimes, it is identified after certain period of time. In other cases, a child normally listens to the people and speaks. Later on, child is unable to listen due to the accidental conditions. Therefore, the deaf are categorized into two broad categories:

1. Deaf by birth

2. Deaf by accident

With the passage of time, they sometimes become completely deaf or partially deaf. In the medical science, it has been observed that the life of the deaf by accident is more stressful than the deaf by birth. As the deaf child grows up in any society, his or her stress level is increased and sometimes, such child loses its confidence. The major reason of this happening is a lack of awareness and knowledge about the deaf community in any society.

Even in some cases, the highly educated persons also do not realize the feelings of deaf communities and hurt them. Therefore, the deaf are leading isolated their lives despite the normal persons might be living with them. Sometimes, the parents and relatives of deaf community avoid talking to them due to their disability. It is a very interesting fact that the deaf feel comfort within their community and discuss a number of problems with each other in their own language which is known as a sign language. In the world, every natural language has its own sign language. The major challenge faced by the deaf communities is a language barrier which makes them withdraw from education and of course there are less opportunities for the handicapped uneducated to lead a quality of life. The deaf community is in minority in any society and their interaction is always with the people who are quite normal. Therefore, it is a dire need of introducing a computerized smart system to overcome the language barrier for the deaf community so that they can easily get quality education and lead their lives with dignity and respect in any working environment. According to Christian Nordqvist, defines hearing impairment as " Hearing impairment, deafness, or hearing loss refers to the inability to hear things, either totally or partially." [1]. According to the definition of Individuals with Disabilities Education Act (IDEA) is "A hearing impairment that is so severe that the child is impaired in processing linguistic information through hearing, with or without amplification." [2]. 
Anwar Ali Sathio et al., International Journal of Emerging Trends in Engineering Research, 9(7), July 2021, 1030 - 1034

\section{Ratio of Deafness in Pakistan}

According to the population census 1998, the total disabled person's ratio was recorded at 2.38 per cent, indicating 80 per cent decline for disability. The current statistics of population has been recorded at 207.744520 million showing an average annual growth rate of 2.4 per cent from the calendar year 1998, when the last census was conducted. The latest 2017, men statistics stands at $106,449,322$ whereas the women stand at 101,314,780, while transgender recorded at 10,418. [3]. The disabilities are being classified by nature according to the previous population census records and can be seen in able No.02 [8].

\section{Global Analysis and Review}

According to the World Report on disability by World Health Organization and World Bank, which were published in 2011, in the report present the ratios of different regimes and explains their initiatives and importance for disabled communities, this analysis shows in the Table No.1

The provisional summary results also show an overall increase in population by 57 per cent over the year 1998, while the population increased by 146.6 per cent since the census of 1981.The census indicates 2.38 percent disabled population registered in the last census in 1998, there were just one million disabled people registered during the 6th Population and Housing Census 2017[4].

The Australian Bureau of Statistics (ABS) reported that the labor force participation rate for people with disability in 2009 was only $54 \%$ [5].

Table No.01 World Report on disability by World Health Organization and World Bank

\begin{tabular}{|c|l|c|c|c|c|}
\hline \multicolumn{6}{|c|}{ Employment rates and ratios in selected countries } \\
\hline S NO. & COUNTRY & YEAR & $\begin{array}{c}\text { EMPLOYMINT } \\
\text { S RATES (\%) }\end{array}$ & $\begin{array}{c}\text { EMPPLOYMINT } \\
\text { OVER ALL } \\
\text { RATIO }(\%)\end{array}$ & $\begin{array}{c}\text { EMPPLOYMINT } \\
\text { RATIO (\%) }\end{array}$ \\
\hline 1 & Australia & 2003 & 41.9 & 72.1 & 0.58 \\
\hline 2 & Austria & 2003 & 43.4 & 68.1 & 0.64 \\
\hline 3 & Canada & 2003 & 56.3 & 74.9 & 0.75 \\
\hline 4 & Germany & 2003 & 46.1 & 64.8 & 0.71 \\
\hline 5 & India & 2003 & 37.6 & 62.5 & 0.61 \\
\hline 6 & Japan & 2003 & 22.7 & 59.4 & 0.38 \\
\hline 7 & Malawi & 2003 & 42.3 & 46.2 & 0.92 \\
\hline 8 & Mexico & 2003 & 47.2 & 60.1 & 0.79 \\
\hline 9 & Netherlands & 2003 & 39.9 & 61.9 & 0.64 \\
\hline 10 & Norway & 2003 & 61.7 & 81.4 & 0.76 \\
\hline 11 & Peru & 2003 & 23.8 & 64.1 & 0.37 \\
\hline 12 & Poland & 2003 & 20.8 & 63.9 & 0.33 \\
\hline 13 & South Africa & 2003 & 12.4 & 41.1 & 0.3 \\
\hline 14 & Spain & 2003 & 22.1 & 50.5 & 0.44 \\
\hline 15 & Switzerland & 2003 & 62.2 & 76.6 & 0.81 \\
\hline 16 & United Kingdom & 2003 & 38.9 & 68.6 & 0.57 \\
\hline 17 & USA & 2005 & 38.1 & 73.2 & 0.52 \\
\hline 18 & Zambia & 2005 & 45.5 & 56.5 & 0.81 \\
\hline
\end{tabular}

According to Australian Bureau of Statistics (ABS) reports in year 2009, it can easily be noticed that the behaviors of global communities are not big different than Pakistan [5]. In USA, the jobs for the disabled, who were facing the same scenarios, were 17 million of working age in the United States.
However, 12 million were unemployed. Most of these people would like to have a job for the disabled...79\% of unemployed disabled people want to have a job [6].

The statistics of the United Kingdom indicates that only $6 \%$ of young people with learning difficulties are having employment. According to Disability Rights UK, the employees with disabilities earn nearly $£ 1$ an hour less than non-disabled workers. Moreover, the Department for Education Green Paper Support and Aspiration found less than one in 20 people with a mental or physical disability who were paid employees [7].

Table 2. DISABLED POPULATION BY NATURE OF DISABILITY [8]

\begin{tabular}{|c|c|c|c|c|c|c|c|c|}
\hline & \multicolumn{8}{|c|}{ Population Disability Classified Records in (\%) percent } \\
\hline & Total & Bind & $\begin{array}{l}\text { Deaf } \\
\text { Nute }\end{array}$ & Crippled & Insane & $\begin{array}{l}\text { Mentally } \\
\text { Restrded }\end{array}$ & $\begin{array}{c}\text { Having } \\
\text { Multiple } \\
\text { Disabilities }\end{array}$ & Others \\
\hline Pakistan & $3,286,630$ & 8.06 & 7.43 & 18.93 & 6.39 & 7.6 & 8.23 & 43.37 \\
\hline Rural & $2,173,999$ & 792 & 7.53 & 20.52 & 5.94 & 732 & 8.23 & 42.55 \\
\hline Trhan & $1,112,631$ & 8.32 & 7.24 & 15.81 & 7.28 & 8.15 & 8.22 & 4.97 \\
\hline
\end{tabular}

\section{PROPOSED RESEARCH METHODOLOGY}

The processing of job restaurant along with the smart technologies has been initiated to manage the communication gaps between the customers as well as staff. This model helps to manage these gaps and also make possibilities for the special people to be treated and offered honored jobs in the deprived and less developed countries.

This model sets standards and makes routine work possible in the restaurants. Although it is for only special people, but all customers can be served along with special people, and due to special arrangements and facilitations, the cost may increase to some extent as compared to the rest of the restaurants. This is not unusual as we pay the bill for special and extraordinary services in the restaurants and even in transporting systems.

The detail model can be viewed in the figure No.02. in which all important processing components have been addressed. The first key component is servant boy who gets the job, other is the manager, who manages all activities from top to bottom. The other necessary modules consist of the accountants, service men, waiters, and sometimes the customers may also be the person who can visit special arrangements of the restaurant. 


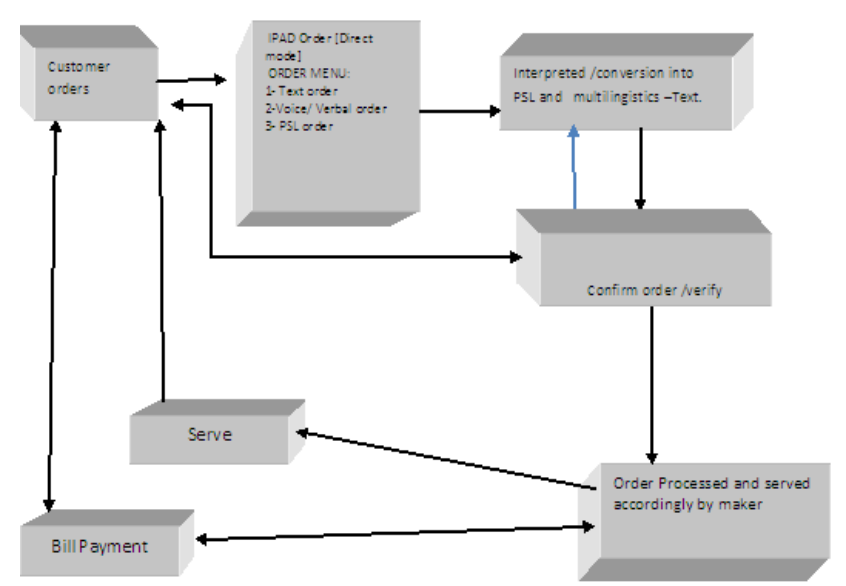

Figure 1 Conceptual Model design for Deaf/Mute persons

\section{REPRESENATION OF FORMAL RATIONALE AND PROPOSED MODEL AND THEORETICAL FRAMEWORK}

The proposed theoretical framework model has been showed in the Fig No.01 for special communities or disable communities. These have been concluded as per following important modules to facilitate the special people who have a problem to communicate and understand the languages. The detail of theoretical framework model cycle stated below in the figure No.02, shows hoe the proceedings and process of every move to be addressed easily and smoothly :

1. Customer gives orders for Juice through device Menu Card.

2. Service Desk gets juice order and confirms order before making orders.

3. Process orders through service desk to Makers/Kitchen - Message released for wait till service ready.

4. When service is ready then it is put forward to customers for service/packing parcel/dispatching.

5. Bill payment processing after service completion to the service desk.

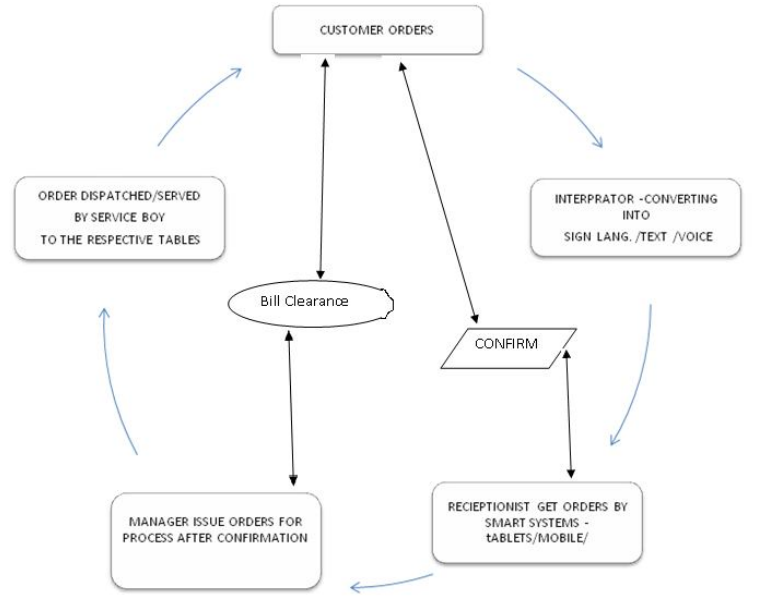

Figure 2: Order Processing Cycle

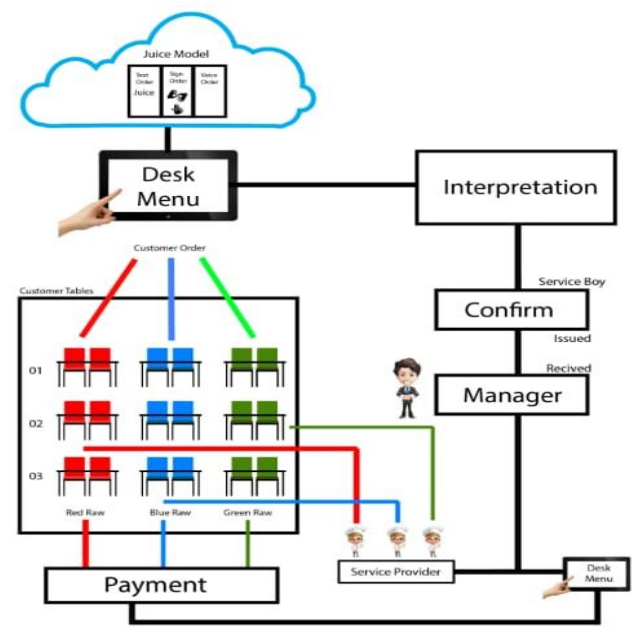

Figure No. 03. Detail Theoretical Model for Deaf/Mute persons

In the Fig No.03 shows that the model design of tables setting system along with all necessary relevant things in the same color to identify the location easily.

\section{SERVICES MODULES AT SPECIAL SPOT FOR SPECIAL PEOPLE}

\section{SMART MAIN MENU CARD}

The main parameter of job model for the special persons is Smart Menu Card which may guide the customers as well as staff to communicate with each other through this display card, this card may be set on every table, or other necessary places where required for all staff, customers etc. This Display - Menu Card for Customer as well as Juice Maker Service Man Icons, Pics., in which symbols may be used for orders-make easy understandings as Banana, strawberry, etc. as shown in the Table No.2.

Table 1 . Menu Cardboard details

\begin{tabular}{|c|c|c|c|c|c|c|}
\hline Sno & Colored Table & $\begin{array}{l}\text { Menu } \\
\text { item }\end{array}$ & $\begin{array}{l}\text { Description } \\
\text { /volume }\end{array}$ & $\begin{array}{l}\text { Service } \\
\text { required }\end{array}$ & $\begin{array}{c}\text { Qty } \\
\text { Glasses/packet }\end{array}$ & $\begin{array}{l}\text { Symbol PSL } \\
\text { code }\end{array}$ \\
\hline 1 & $\begin{array}{l}\text { Blue Table all } \\
\text { Table accessor ies in } \\
\text { blue colors as } \\
\text { Glasses, tables, } \\
\text { tr ays, covers, } \\
\text { tissues etc. }\end{array}$ & $\begin{array}{l}\text { Banana } \\
\text { juice }\end{array}$ & $\begin{array}{l}\text { Smal glass, full } \\
\text { glass, parcel etc. }\end{array}$ & $\begin{array}{l}\text { Packing } \\
\text { parcel }\end{array}$ & $\begin{array}{c}\text { Number Pad } \\
\text { for select the } \\
\text { quantity }\end{array}$ & $\begin{array}{l}\text { Conversion } \\
\text { of order into } \\
\text { PSL strings }\end{array}$ \\
\hline 2 & $\begin{array}{l}\text { Pink Table } \\
\text { all } \\
\text { Table accessor ies in } \\
\text { Pink colors as } \\
\text { Glasses, tables, } \\
\text { trays, covers, } \\
\text { tissues etc. }\end{array}$ & $\begin{array}{l}\text { Straw } \\
\text { berry } \\
\text { juice }\end{array}$ & $\begin{array}{l}\text { Small glass, full } \\
\text { glass, parcel etc. }\end{array}$ & $\begin{array}{l}\text { Table } \\
\text { service }\end{array}$ & $\begin{array}{c}\text { Number Pad } \\
\text { for select the } \\
\text { quantity }\end{array}$ & $\begin{array}{l}\text { Conversion } \\
\text { of order into } \\
\text { PSL strings }\end{array}$ \\
\hline 3 & $\begin{array}{l}\text { Green Table all } \\
\text { Table accessor ies in } \\
\text { Green colors as } \\
\text { Glasses, tables, } \\
\text { tr ays, covers, } \\
\text { tissues etc. }\end{array}$ & Mix juce & $\begin{array}{l}\text { Small glass, full } \\
\text { glass, parcel etc. }\end{array}$ & $\begin{array}{l}\text { Table } \\
\text { service }\end{array}$ & $\begin{array}{c}\text { Number Pad } \\
\text { for select the } \\
\text { quantity }\end{array}$ & $\begin{array}{l}\text { Conversion } \\
\text { of order into } \\
\text { PSL strings }\end{array}$ \\
\hline
\end{tabular}


Anwar Ali Sathio et al., International Journal of Emerging Trends in Engineering Research, 9(7), July 2021, 1030 - 1034

\section{SMART SUB MENU CARD}

This sub menu card consists of detailed structure of data which is available at the restaurant, for example, juice restaurant, so sub menu card states the list of available flavors, rates, etc. This is put on display with icons and PSL languages to communicate with the customers, service boys and all other staff members as well. The detail may be viewed in the Table No.3.

Table 2. Juice Rates Descriptions with pictures and icons/symbols.

\begin{tabular}{|c|c|c|c|c|c|}
\hline \multirow{2}{*}{$\mathrm{SN}_{0}$} & \multirow{2}{*}{ Juice $\mathrm{N}_{0}$. } & \multirow{2}{*}{ Menu } & \multirow{2}{*}{$\begin{array}{c}\text { Description / } \\
\text { Volume }\end{array}$} & \multirow{2}{*}{ Price Rs. } & Service Mode \\
\hline & & & & & parcel/packing \\
\hline 1. & I & Orange Juice & Small glass & $50 \%$ & To Serve \\
\hline 2. & II & Orange Juice & Full glass & $100 \%$ & To Serve \\
\hline 3. & III & \begin{tabular}{|l|} 
Mill Shake \\
Banana Juice
\end{tabular} & Small glass & $80 /$. & To Serve \\
\hline 4. & IV & \begin{tabular}{|l|} 
Mill Shake \\
Banana Juice
\end{tabular} & Full glass & $160 /-$ & Parcel Packing \\
\hline 5. & V & Mix fruit Juice & Small glass & $90 \%$ & To Serve \\
\hline 6. & VI & Mix fruit Juice & Full glass & $180 /-$ & To Serve \\
\hline
\end{tabular}

\section{SERVICE REPORT SYSTEMS}

This module captures all the ongoing service report systems with updates and records, it will guide all the concerned stockholders being informed about the order processing status, necessary information for all involved persons. This is shown in Table No4.

Table 3. Order process- reporting systems

\begin{tabular}{|l|c|c|}
\hline $\begin{array}{c}\text { Table No. } \\
\text { Color }\end{array}$ & Order Status & Remarks - conclusion \\
\hline Red table & Cancelled & By customer request \\
\hline Blue table 01 & Processing & Ready In 05 minutes \\
\hline Green 01 & $\begin{array}{c}\text { Served by Boy-00A-1- } \\
\text { Asad }\end{array}$ & Served \\
\hline
\end{tabular}

\section{SAFE SERVICE MODULE}

The safety of business and customer inside the premises is considered on priority level, keeping in view that an alert and information system by the management framed to minimize the risk level for customers and business owners. This sub module system displays the current record of employees and available assets, seats etc. with pictures along with icon information.

Table 4. Table Service - Person Allocation Photos of allocated person used as icon.

\begin{tabular}{|l|c|c|}
\hline Table No. -Color & Service boy name & Code name \\
\hline Blue-01 & Asad & B-SBN-001 \\
\hline Green-01 & Akram & G-SBN-002 \\
\hline Red-01 & Aslam & R-SBN-003 \\
\hline
\end{tabular}

\section{PROMINENT FEATURE OF PROPOSED MODEL}

There are so many features relating to this proposed job model for the special people (Deaf /Mute) who can be motivated, the main features are given as under:

1. The local problems which are very small but very irritating ones, the isolation and being displayed as a burden of society, this will decrease these kinds of problems in a very simple and short duration.

2. The issues of human rights being faced by the isolated and deprived persons can also be resolved by enabling them as equal and parallel social partner of the society.

3. This job model is a social and impressive job model, which ensures the good behavior against distinction between either mental or physical impairment and disability having social oppression by the society

4. The ratio of these special people is very small; however, they need special attention to seek attention of the society so that they may understand and stand along with normal people of our society.

\section{CONSEQUENCES / RESULT}

When this conceptual model is implemented in any big city, it will present a platform as a milestone in the society. It will encourage those who think that it may not be possible, and it will offer an opportunity for the deaf. They ignore deliberately these deprived special people. The results of this model may not be compared with normal hi-tech job models, but this proposed job model help the affected people. These special people need our attention and care to improve the quality of life.

\section{FUTURE WORK}

The future work about this model and field is that all hotels make possible a corner equipped and extension for this model implementation. Using PSL experience, this model can also be implemented into other prevailing global sign languages which help in job easiness and become equal opportunity competitor in the society.

\section{REFERENCES}

[1] Christian Nordqvist, "What's to know about deafness and hearing loss" accessed on September 2017 https://www.medicalnewstoday.com/articles/249285.php. [2]https://www.specialeducationguide.com/disability-profile s/deafness/ accessed on September 16, 2017

[3] https://www.pakistantoday.com.pk/national/ accessed on September 16, 2017 BY APP 
Anwar Ali Sathio et al., International Journal of Emerging Trends in Engineering Research, 9(7), July 2021, 1030 - 1034

[4]https://dailytimes.com.pk/writer/dna/, accessed on 12th September,2017.

[5]reports,http://www.abs.gov.au/AUSSTATS/abs@. nsf/Lookup/4102.0Main+Features40March+ Quarter+2012, accessed on September,2017

[6]http://www.depression-help-for-you.com/job-for-the-disa bled.html, accessed on September,2017

[7]http://www.educationengland.org.uk/documents/pdfs/201 1-green-paper-sen.pdf, accessed on September,2017

[8]http://www.pbs.gov.pk/content/disabled-population-natur e-disability, accessed on September,2017 census statistics 